\title{
Ethical Media Content Adjustment between Croatian and European Union Regulations - Following Local Elections 2013 in Lika-senj County
}

\author{
Vlatka Ružić* \\ University of applied sciences, Nikola Tesla, Gospić, Croatia \\ *Corresponding author: vlatka.ruzic@gmail.com
}

Received June 16, 2014; Revised July 14, 2014; Accepted July 17, 2014

\begin{abstract}
Mass media in Croatian media space is generally defined according to profitability and is based on the definition of mass media as industrial and commercial organisation that does not produce and distribute information but goods; in that situation hidden advertising appears in terms of income decreasing ( especially during political campaigns); that kind of situation is in direct contradiction with media freedom as crucial pre-condition of ethical principles achievement. On the example of the analysis of media content published in electronic and printed media during the campaign carried out in 2013. - local elections in Lika-senj county, this work will show how complex are ethical doubts that journalists meet in open societies in which media freedom is very large; point out the proportion and examples of ethical standards violation and destabilisation of the border between good and bad taste by violation of privacy, augment of information damage by unfair reporting, and publisher or interest groups pressure which results in placing incomplete, subjective, biased or incorrect information to the public. The aim of this work is to (by methods of incomplete induction, deduction, description, analysis and sample method) indicate on insufficient balance of media content between Croatian and European Union regulatives, the lack of critical public opinion in media reporting and insufficient adopted freedom and responsibilities in media content creation.
\end{abstract}

Keywords: ethics, media content, hidden advertising, elections

Cite This Article: Vlatka Ružić, "Ethical Media Content Adjustment between Croatian and European Union Regulations - Following Local Elections 2013 in Lika-senj County.” Journal of Finance and Economics, vol. 2, no. 5 (2014): 162-165. doi: 10.12691/jfe-2-5-5.

\section{Introduction: European Ethical Regulation of Media Content}

Defining ethical rules is characteristic for all professions, not just for journalism, with a strong difference that lack of ethics in none other profession has such wide consequences considering the range of public it affects. In Europe the set of media ethical rules is known as „, ethical code“ or „the cannons of journalism“ and are brought by professional journal associations or individual subjects that publicize and publish the news. Independently on the publisher, these documents with certain specificity contain same basic elements that comprise principles of truth, punctuality, objectivity, honesty and public relevance where at the same thing is applied on the process of information gathering as well as its distribution to the public. Other very important principle is the principle of damage limitation that usually includes omission of details in terms of names of the minors, victims and information that could harm someone`s reputation. European journalistic ethical codes include taking care of discrimination in terms of race, sex orientation, and psychological and mental incapability.
Council of Europe has brought „"The 1003 Resolution“ in 1993. that recomends journalists to respect the presumption of innocence especially in sub judice cases. Summarised journalist principles are best shown by journalism organisation [10] that sets out all together nine ethical principles that journalists should comply while obeying their tasks:

1. First obligation of journalism is the truth journalism truth is a process that begins with professional information gathering and checking because democracy depends on the fact if the public has accurate information upon which conclusions could be drawn out;

2. Basic loyalty of jounalism towards the public - it creates the basis for authenticity and includes equal representation of all society groups;

3. The base for journalism is the discipline of verification - this discipline is often not recognised as relevant but it divides journalism from other forms of communication (propaganda, fiction or fun);

4. Journalists have to maintain independence towards the subject they inform about - independence is the base for the development of journalism; in this context it comprises the independence of opinion, intellectual honesty and capability of reporting 
without showing support towards certain group or outcome;

5. Journalism has to serve as an independent monitor of power - journalists have the ability to serve as public keepers referring to those whose power has the greatest influence on public;

6. Journalism must secure space for public critic and compromise - media are usually carriers of public discussion and as such should lean towards fair representation of different points of view instead pointing out just one side;

7. Journalist have tendency towards making the news interesting and important- journalism one has to find balance between what public knows it wants and what it cannot anticipate it wants; journalism has to constantly question what information has the biggest importance for the public and in what form;

8. Journalist have to keep the news proportional and whole - that understands not leaving out contribute of truth because journalism is ( as a form of analogy) sort of cartography; it creates directions in terms how to move through the society;

9. Users of the information have to be able to make their own conclusions.

The value of the above mentioned principles comes from the fact that those media that are countable have envious number of serious users while will others attract individuals and groups that don't care for the truth but realisation of individual ( often low) impulse; that especially refers to electronic media.

\section{Features of Croatian Media Space from the Ethical Reporting Point of View}

Basic characteristic of reporting in electronic media in the Republic of Croatia is the lack of an adequate society culture level; ethical issues of published content is also questionable while at the same time the ignorance of the rules of pubic communication is also notable [4]. The reasons for that are different: from the fact that the part of internet portals are founded by individuals who have no journalism education while at the same time articles are published by persons who have never met with term „journalism ethics“; the fact that part of electronic media is created with the intention to control and direct primary political contents i.e. with the goal to create politic information for wide public whereat the attempts to enlarge the damage from information is often not left out;; unfair reporting or placement of incomplete, subjective or totally biased i.e. incorrect information placement that has the aim to damage reputation to an opponent political option or influence attitudes the electors about certain political option is also very notable.

Research done within the PhD theses in December 2007. and January 2008. [4] in the Republic of Croatia has confirmed the basic assumption according to which electronic issues of Croatian major daily newspapers (Jutarnji list, Večernji list i 24sata) do not pay enough attention to ethical aspects of the content published. On daily basis they contain the speech of hate, aspersions ; giving attitudes about individuals, groups, and events without evidence, as well as placing information that has not been verified from more than one source, while dirty language that contains curses dominates in readers' comments underneath the articles. The same research [4] has confirmed that the check of unethical contents in readers comments is very low or does not exist.

Interest for the media that shows lack of ethical content is increasingly growing. Research done in 2011. [7] shows that the television continues to lead as information source ( for 58\% of the citizens); internet comes second (19\%) before newspapers (10\%) and radio (6\%) while only $8 \%$ of citizens are active in reviewing the information from various sources. All the above mentioned can lead to the conclusion that internet as a source of information has relatively high rating; in context of all that information a fact should be implemented that exactly internet presents a media space in which ethical principles are bypassed or not implemented at all and that it has significant impact on creation of public opinion especially with younger age groups which is confirmed also by the results of the research [5]:

Table 1. What media has the most credibility among young people?

\begin{tabular}{l|l}
\hline Type of media & $\%$ \\
\hline Internet & $48 \%$ \\
\hline Television & $29 \%$ \\
\hline Daily newspapers & $12 \%$ \\
\hline Radio & $6 \%$ \\
\hline Other & $5 \%$ \\
\hline
\end{tabular}

\section{Analysis of Media Content Published in Electronic and Paper Media during Electoral Campaign for Local Elections in 2013. in Lika- senj County, Croatia}

In Lika-senj county permanent association of Croatian television with headquarters in town Gospić (national television owned by the government) is organised; published media as well as electronic publications of those media are covered by associates in order that they cover major national newspapers ( Novi list, Jutarnji list and Večernji list and 24hours) while Jutarnji list is covered by journalists in town Karlovac. The same is valid for commercial television coverage - they do not have permanent associations in the county but they hire associates of the nearest associations (town Rijeka for NovaTV and town Zadar for RTL television - both commercial televisions).

Until 2009. newspapers and national and commercial televisions were the only source of information for the inhabitants of Lika-senj county; information on all contents (including political ones) were available only from those sources. From the beginning of 2009. an expansion of internet portals occurs which makes local news much more available to the inhabitants of Lika Senj county. Today in Lika-senj county there are altogether five active internet portals that do not exist as electronic issues of printed newspapers, of which two have editoral boards located in town Gospić, two in town Otočac (one of which is an internet television of local character that sometimes does shootings for commercial televisions on national level) and one in the town Korenica. From all five above mentioned portals one is registered as an informative portal for Lika-senj region and wider, other as 
regional journalistic-informative portal for the region of Lika-senj county, while others have no clearly defined area or region of activities; from all these portals three have the Decision on provider of electronic publications inscription in the Book of electronic publication provider determinated by the Council of electronic media available on their website according to the article 80. of Law of electronic media (Narodne novine 153/09, 84/11) as well as Article 9. of Set of rules for media service and electronc publications providers („Narodne novine“ No. 93/11). Official visit analysis of all portals has not been done but according to Google analytics visit measurement, unique daily visit of the most visited portals ranks between 3.000 and 5.000 unique visitors. The aim of the research was to determine ethical vex in articles published on front pages of the portals as well as in published editions of national newspapers in articles that were referred to local elections in Lika -Senj county, published within one month. In the research two hypotheses have been presented:
1. articles of mentioned media has in proportion great number of ethical vex;

2. the domination of ethically vex articles is present on internet portals ( electronic media)

In order to confirm or deny presented hypotheses a method of quantitative content analyses of published articles ( as unit of content analysis) was used. The aim was (with the help of quantitative indicators) to gain the data about the amount/quantity of ethical vex in mentioned media. For the analysis and categorisation of articles as well as in interpretation of the results a quantitative analysis was used. During the local elections of 2013. campaign, researched portals have published a great number of articles, from which altogether 70 published articles in all five portals were analysed, from April 17. to May 17. 2013. Furthermore, an analysys of altogether 21 article about local elections in Lika-senj county were published in national printed newspapers, and were also researched in the same time period.

Table 2. Media content analisys - local elections 2013 in Lika-senj county ( published in electronic and printed medai from 17.04-17.05.2013.)

\begin{tabular}{|c|c|c|c|c|}
\hline Observed feature & $\begin{array}{l}\text { Articles in electronic media } \\
\text { /portals from altogether } 70\end{array}$ & $\begin{array}{l}\text { amount } \\
\text { in } \%\end{array}$ & $\begin{array}{l}\text { Articles in newspapers } \\
\text { (from altogether 21) }\end{array}$ & $\begin{array}{c}\text { Amount } \\
\text { in } \%\end{array}$ \\
\hline Presenting only one side in confrontation & 47 & $67 \%$ & 0 & $0 \%$ \\
\hline Violation of privacy of political candidates & 21 & $30 \%$ & 2 & $10 \%$ \\
\hline Information damage enlargement & 53 & $76 \%$ & 5 & $7 \%$ \\
\hline Unfair reporting ( inappropriate and elfishly reporting) & 38 & $54 \%$ & 1 & $5 \%$ \\
\hline $\begin{array}{l}\text { Visible correlation between sponsoring and affirmative } \\
\text { articles (founder/sponsor influence) }\end{array}$ & 39 & $56 \%$ & 13 & $62 \%$ \\
\hline $\begin{array}{l}\text { Articles that implicate criminal activities of a candidate } \\
\text { of certain political party in their title }\end{array}$ & 6 & $9 \%$ & 0 & $0 \%$ \\
\hline $\begin{array}{l}\text { Articles that lead to delusion in terms of estimate of } \\
\text { political victory ( making one candidate more favourable) }\end{array}$ & 35 & $50 \%$ & 0 & $0 \%$ \\
\hline $\begin{array}{l}\text { Articles that implicate immoral personal characteristics of } \\
\text { political candidates }\end{array}$ & 26 & $37 \%$ & 2 & $10 \%$ \\
\hline Referring to anonimous sources & 18 & $26 \%$ & 7 & $33 \%$ \\
\hline
\end{tabular}

Source : author analysis.

From the above presented analysis following conclusions can be drawn:

- Ethical media content is much more present in printed media/newspapers than in electronic/internet portals;

- Printed media has less intention to lead to delusion in terms of estimation of winner i.e. they have the tendency to base eventual estimates on official poll results made by accredited agencies, while on local level poll results could be manipulated by owner/ editor of electronic media or even by readers themselves if they are allowed to vote more times than one;

- Number of articles in which a line of good taste is crossed is much higher in electronic than in printed media;

- Electronic media show much more tension to quote anonymous sources and present only one side of the story than printed media;

- Printed media have the tendency to publish information about political candidates in terms of their coalition ambitions and origin of their property i.e. referring at political trades or political credibility of a candidate, but are less likely to invade private life of candidates; electronic media on the other hand often invide privacy of some political candidates what could maybe be explained with greater local interest in every part of life of political candidates.
With taking into consideration that in small places like town Gospić and Otočac is easy to determine political orientation of the owner of electronic portal or a journalist, or to obtain information about the sources of financing, impact of the owner or editor on selection of content that will be published as well as the amount of ethical level in printed media is significant, i.e. influence of sponsors on the number and content of articles published in electronic media can be determined; based on the number of banners and commercials, „ordered“ articles can be easily defined, while the level of ethical issues become more or less „aimed“. At the same time it is important to understand that sponsoring or advertising is not prohibited i.e. that it is according to article 35. of Law of electronic media („Narodne novine“ 153/09) allowed in time of electoral advertising; it is however understood that advertising will not affect ethical side of reporting but there is great impact on the public with hidden advertising.

Generally speaking ethical issues of media content is less present in electronic media where the rules of public communication that sometimes lead to violation of human rights are consciously left out. Some electronic portals are put down on publishing banal articles and so called „dirty underwear" of political candidates in front of the public; in that case ethic is not a task of the one that sends the message but the task of the one who receives the message, even more because the one that receives the message becomes also communicator in electronic portals. 
The reasons for described situation are not to be found in defining of media politics in the Republic of Croatia that has not followed fast development and radical changes of media and their social role. Media politics is expected and asked for to direct media more efficiently, based on precise evidence and information; at the same time Croatian media policy has to constantly lean on European instructions and regulative, which does not always occur. Those are the reasons why media politics has to continue to adjust to transitional public sphere, growing of new technologies and processes of individualisation of media consumption, as well as to create new sorts of communication interactivities. Although legislator in article 1.a of the Law of electronic media ( NN 80/13) has by name stated out all european directives ( alltogether nine of them) whit which the Law is adjusted, none of them relates to ethical aspect of media functioning. Media politics presents itself mostly in bringing and improving of laws and regulations, implementation of different state and state-owned organisations (agencies) and overview of all media activities (regulation) by which the State is defined as key element of media politics. Although the position and social role of media is rapidly changing, croatian media are still not founded to be autonomous, different specialized and in certain level in ethical sense selfcontrolling system of informing, education and fun. Media never the less is presenting as social and cultural change participants but that role is primarily seen in growing number and diversity of media and the social impact of new media.

\section{Conclusion}

It is a general impression that in journalism a great number of ethically controverse articles can be found, by which stands a clear domination of those articles ( as well as the lack of control) in electronic media. The results of a done research at the same time in electronic and printed media in microlocation of Lika-Senj county has confirmed both presented hypotheses. The biggest number of determined ethical vex from altogether nine categories of ethical vex refer to information damage enlargement, presenting only one side in conflict, unfair reporting, spotted corelation between sponsoring and afirmative articles and anonnimous sources in printed media. Spoted braking of ethics of journalism could be primary explained with sensationalism that is ever more present in media as a result of highlighted commercial services of media in which information becomes good that needs to be sold as soon as possible and for as much money as possible. In order to fulfill the first goal of media - attracting attention of the readers and gaining as much as profit as possible basic rules of quality journalism are neglected as well as the responsibility towards the readers / recipients of the information. Although the conducted research has comprised smaller number of articles ( small in terms of content of analysed articles) and as such cannot give an adequate answer on real quantity of ethical controversy in researched media, given results are indicative for reevaluating of credibility and ethical aspects of reporting.

\section{References}

[1] Kangrga, M. Ethics and journalism, Media research Journal 4 (1), 1998, 17-27.

[2] Malović, S. et al. Etika novinarstva. 2007 ICEJ Zagreb

[3] Majstorović, D. Etički prijepori i vjerodostojnost dnevnih novina, Medijske studije (1-2), 2010., 55-64.

[4] Obradović, Đ. Etičke dvojbe u mrežnim izdanjima dnevnih listova, Sveučilište u Zadru, 2009., Zadar (doktorska disertacija).

[5] Peruško, Medijski sustav i medijska politika u Hrvatskoj -20102011., Centar za istraživanje medija i komunikacije, Fakultet političkih znanosti, Sveučilište u Zagrebu, 2012., Zagreb.

[6] Poler, M. Što je novinarska etika?, Medijska istraživanja 4,2009., Zagreb, (1): 29-45.

[7] http://www.gfk.hr/public_relations/press/press_articles/008744/in dex.hr.html (12.10.2013).

[8] Gfk, Neka zapažanja o mladoj online populaciji u Hrvatskoj (http://www.gfk.hr/public_relations/press/press_articles/008744/in dex.hr.html, 12.10.2013).

[9] Zakon o elektroničkim medijima (NN 153/09).

[10] http://www.journalism.org/resources/principles-of-journalism, 12.10.2013. 